\title{
Organotin compounds and aquatic bacteria: a review*
}

\author{
J. J. Cooney \\ University of Massachusetts; Boston, MA 02125-3393, USA
}

\begin{abstract}
Organotins are toxic to microorganisms. Trisubstituted organotins $\left(\mathrm{R}_{3} \mathrm{SnX}\right)$ are considered more toxic than disubstituted $\left(\mathrm{R}_{2} \mathrm{SnX}_{2}\right)$ or monosubstituted $\left(\mathrm{RSnX}_{3}\right)$ compounds, and tetrasubstituted compounds $\left(\mathrm{R}_{4} \mathrm{Sn}\right)$ are not considered toxic. In the $\mathrm{R}_{3} \mathrm{Sn}$ series propyl-, butyl-, pentyl-, phenyl- and cyclohexyltins are the most toxic to microorganisms. Toxicity towards aerobes in the $\mathrm{R}_{3} \mathrm{Sn}$ series is related to total molecular surface area and to the octanol:water partition coefficient, Kow, which is a measure of hydrophobicity. Care must be taken when testing the toxicity of tin compounds in the laboratory, for a number of biological, chemical and physical factors can influence the apparent toxicity. Although TBT is generally the most toxic of the butyltins, there are instances where monobutyltin (MBT) is as toxic, or more toxic, than TBT to microorganisms. Thus, debutylation in the sequence TBT $\rightarrow$ DBT $\rightarrow \mathrm{MBT} \rightarrow$ Sn does not detoxify TBT for all microorganisms. Some microorganisms can methylate inorganic or organic tins under aerobic or anaerobic conditions. Methylation can also occur by chemical means and the relative contributions of biotic and abiotic mechanisms are not clear. It is difficult to isolate a pure culture which can methylate tin compounds aerobically, and it is difficult to isolate a pure culture which degrades TBT, suggesting that microbial consortiums may be involved in transformations of organotins in the aquatic environment. Methylation and debutylation alter the adsorbtivity and solubility of tin compounds; thus, microorganisms can influence the environmental mobility of tin. TBT-resistant microorganisms can be isolated, and in some of them resistance to TBT can be plasmid-mediated.
\end{abstract}

\section{INTRODUCTION}

The efficiency with which a boat moves through the water depends on the smoothness of its hull. Increasing the average hull roughness by only $10 \mu \mathrm{m}$ can increase fuel consumption by as much as $1 \%$. If barnacles are present on the hull, they can increase roughness by several centimetres. Therefore, boats which operate in marine or estuarine waters are coated with antifouling paints. The principal types of paints used contain either copper or tributyltin (TBT) as their active antibiologic agent. TBT is the more effective of the two, lasting for up to 7 years, while vessels coated with copper-containing paints are painted yearly. The potential fuel saving on US vessels by using paint with TBT is estimated at US\$ $\$ 300-400$ million per year, based on crude oil priced at US\$ 16 per barrel. This would represent a saving of 2 billion gallons of fossil fuel (Champ \& Pugh, 1987). TBT is also used in coatings or treatments for other surfaces immersed in water, including intake pipes for cooling systems, pilings, buoys, oil rigs, cables and lines, and nets and cages used in aquaculture. Paints containing TBT are the only practical means

\footnotetext{
- The literature review for this paper was completed in July, 1992. 
for controlling the zebra mussel, Dreissena polymorpha, which is a major freshwater fouling pest (Mackie et al., 1989).

Some 30000 tons of organotins are produced each year, representing about $5 \%$ of the tin mined. Tin may have more of its organometallic derivatives in use than any other element (Blunden et al., 1984; Champ, 1986; Davies \& Smith, 1982; Maguire, 1987). Other organotins are widely used in industry and agriculture. Their largest single use is as stabilizers for polyvinyl chlorides, followed by their uses as antibiologic agents and as chemical catalysts (Blunden et al., 1984; Davies \& Smith, 1980; Thompson et al., 1985). Much of the organotins used each year will eventually reach the environment. In the aquatic environment, particular attention has been focussed on methyltins, which can be formed there, and are used in industry, and on TBT which is toxic to a number of nontarget organisms.

TBT causes morphological aberrations in oysters and mussels (Waldock \& Thain, 1983). Considerable attention has been given to effects on the dogwhelk, Nucella lapillus, which in TBT-contaminated waters exhibits a condition known as imposex, wherein female animals grow male sex organs and the population cannot reproduce (Gibbs et al., 1991; Spence et al., 1990); exposure to TBT leads to a significant increase in testosterone (Spooner et al., 1991). Imposex can occur at concentrations as low as $1 \mathrm{ng}$ TBT-Sn per litre (1 part per trillion, 8.4 pM) (Gibbs \& Bryan, 1986; Oehlmann et al., 1991). Molluscs may be unusually sensitive because they have relatively low activities of cytochrome $p-450$ and mixed function oxidases which lead to TBT accumulation (Lee, 1991). A variety of other macro- and microorganisms is sensitive to TBT (Cooney \& Wuertz, 1989; Hall \& Pinkney, 1985; Thayer, 1984; Thompson et al., 1985). In general, a high octanol:water partition coefficient, Kow, and a high total molecular surface area, predict greater toxicity (Eng et al., 1988). As with many environmental stressors, the early life stages are the most sensitive (Beaumont \& Budd, 1984; Fent, 1991; Oehlmann et al., 1991). TBT can accumulate in the flesh of shellfish (Cullen et al., 1990; Davies et al., 1986), and in finfish (Short \& Thrower, 1986) held in pens treated with paint containing TBT - thus entering the human food chain.

The most common quantification methods involve solvent extraction, derivative preparation to facilitate separation, and quantification of individual tin species by atomic absorption spectrometry, flame photometry or by mass spectrometry (Ashby et al., 1988; Blair et al., 1986; Han \& Weber, 1988; Maguire, 1987; Quevauviller \& Donard, 1990; Stallard et al., 1989; Valkirs et al,, 1987).

In the aquatic environment, organic and inorganic tin compounds can be concentrated as much as 10000 -fold in the surface microlayer and up to 4000 times in oily sediments (Cleary \& Stebbing, 1985; Maguire, 1987; Maguire \& Tkacz, 1987). Tin may be associated with dissolved organic matter (Froelich et al., 1985; Donard \& Weber, 1985), but most of the pollutant tin in rivers becomes attached to suspended particulates (Byrd \& Andreae, 1982; Maguire \& Tkacz, 1985) and concentrations are about three orders of magnitude greater in sediments than in the water column (Valkirs et al., 1986), and are a probable source for uptake by benthic deposit feeders (Langston \& Burt, 1991). Salinity and $\mathrm{pH}$ influence binding to sediments (Harris \& Cleary, 1987; Randall \& Weber, 1986; Unger et al., 1987). Organotins also occur in freshwaters and their sediments (Fent \& Hunn, 1991; Schebek \& Andreae, 1991) and in sewage sludge (Fent \& Mueller, 1991; Spiegel et al., 1985). Concentrations of TBT and its degradation products dibutyltin (DBT) 
and monobutyltin (MBT) are higher in harbours and marinas than in open water (Alzieu et al., 1990; Cullen et al., 1990; Maguire, 1987; Wuertz et al., 1991; Thompson et al., 1985; Valkirs et al., 1986), as expected, since TBT leaches from antifouling paints.

Recently-deposited sediments contain about ten times as much tin as sediments laid down before the industrial revolution (Seidel et al., 1980). Evidence from laboratory microcosms suggests that TBT and its degradation products can accumulate in seagrass beds (Levine et al., 1990). It is to be expected that organotins will interact strongly with benthic organisms.

Organotin compounds also interact with microorganisms, and these interactions have largely been overlooked in considerations of the environmental fate and effects of organotins. It is important to understand these interactions, because microorganisms mediate a number of global processes and because they are at the base of food webs. The purpose of this paper is to summarize what is known of these interactions and to present some experimental results which illustrate the interactions.

\section{ACTION OF TIN COMPOUNDS ON MICROORGANISMS}

Pioneering work in this area was begun in the 1950s at the Institute for Organic Chemistry at Utrecht, the Netherlands (Sijpesteijn et al,, 1969; Luijten, 1972). Tin compounds are toxic to some algae, fungi and bacteria, and the topic has been reviewed (Cooney \& Wuertz, 1989). It is generally considered that toxicity decreases in the order $\mathrm{R}_{3} \mathrm{SnX}>\mathrm{R}_{2} \mathrm{SnX} \mathrm{X}_{2}>\mathrm{RSnX}_{3}$ (Fig. 1). The anion, $\mathrm{X}$, has little effect on toxicity. Propyl-, butyl-, pentyl-, phenyl- and cyclohexyltins are generally most toxic to microorganisms but, as shown in Table 1, the effect varies from organism to organism, and ethyltins can also be effective. Similarly, the suggestion that Gram-negative bacteria are more sensitive to organotins than are Gram-positive bacteria does not always hold. The general rule that $\mathrm{R}_{\mathbf{4}} \mathrm{Sn}$ 's and inorganic tin are not toxic does not always apply (Table 1). Organotins and inorganic tin are toxic to some organisms in mixed populations (Hallas \& Cooney, 1981b; Pettibone \& Cooney, 1988; Wuertz et al., 1991) and to pure cultures (Belay et al., 1990; Boopathy \& Daniels, 1991; Hallas \& Cooney, 1981a; Hallas et al., 1982b; Soracco \& Pope, 1983; Wuertz et al., 1991; and others), including indicator bacteria (Pettibone \& Cooney, 1986).

Although the sequence of toxicity $\mathrm{R}_{3} \mathrm{Sn}>\mathrm{R}_{2} \mathrm{Sn}>\mathrm{RSn}$ applies to macroorganisms and to many microorganisms, it does not hold for all microorganisms. For example, MBT was more effective than DBT at causing release of potassium from some marine yeast (Fig. 2, Cooney et al., 1989), and MBT and inorganic tin were more effective than TBT or DBT in inactivating bacteriophage T4 (Fig. 3, Doolittle \& Cooney, 1992). Moreover, MBT is more toxic than TBT to methanogenic and sulfate-reducing bacteria (Belay et al., 1990; Boopathy \& Daniels, 1991). These results do not agree with the relation verified with a variety of organisms (Eng et al., 1988), that increasing toxicity of organotins correlates with increasing total molecular surface area. Results with methanogens are not due to methanogens being anaerobes because TBT was more effective than MBT against Escherichia coli, whether the bacterium was grown aerobically or anaerobically (Boopathy \& Daniels, 1991). These toxic effects of DBT and MBT suggest that TBT should not be considered detoxified for microorganisms simply because it has been partially debutylated. 


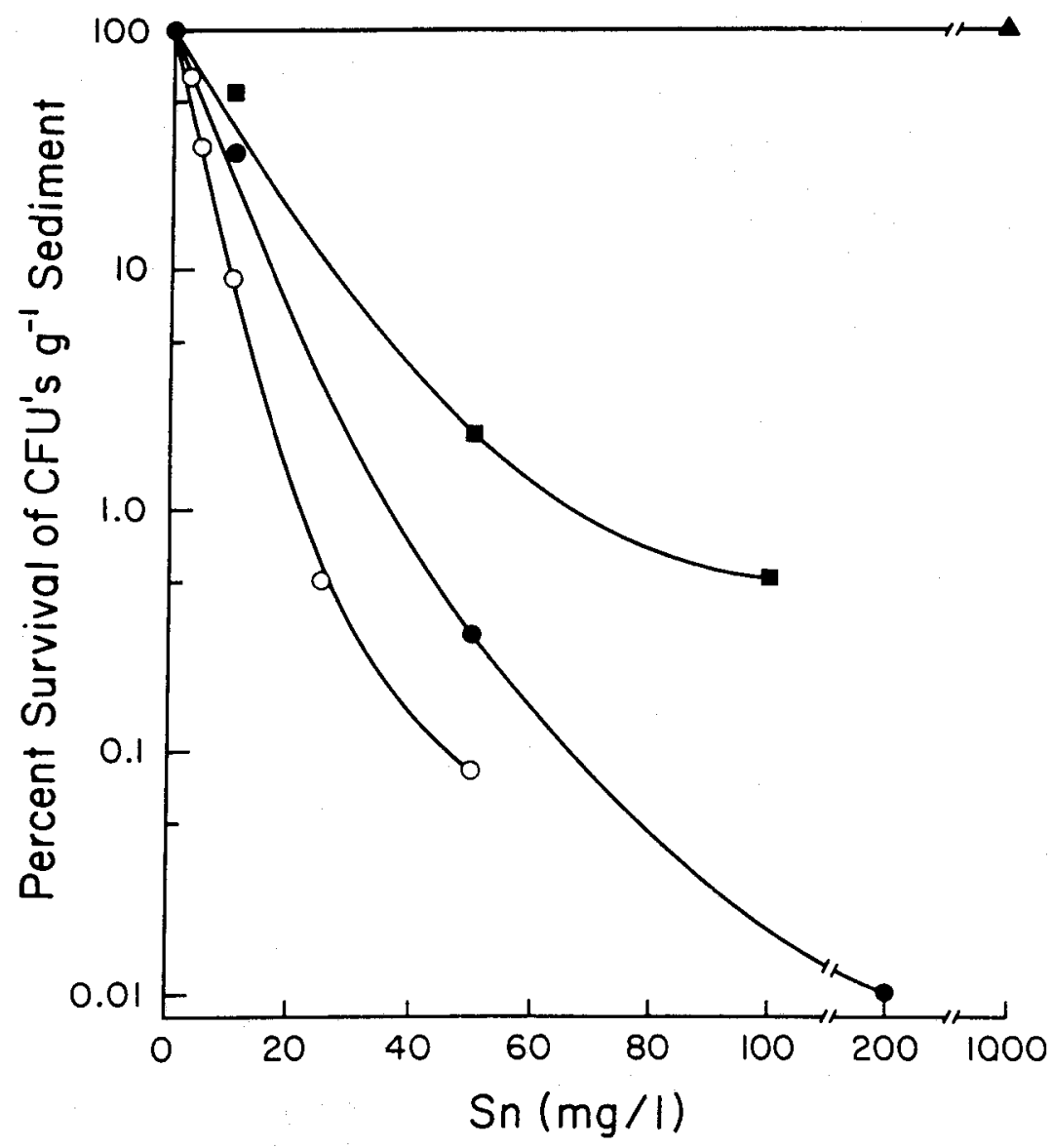

Fig. 1. Effect of methyltin compounds on total viable counts of natural populations from sediments in Boston Harbour. Tin was added as $\mathbf{n}, \mathrm{CH}_{3} \mathrm{SnCl}_{3} ;,\left(\mathrm{CH}_{3}\right)_{2} \mathrm{SnCl}_{2} ; \mathrm{O},\left(\mathrm{CH}_{3}\right)_{3} \mathrm{SnCl}_{i} \mathbf{\Delta},\left(\mathrm{CH}_{3}\right)_{4} \mathrm{Sn}$. Total viable counts in control suspensions which did not receive any addition of tin ranged from $6.6 \times 10^{6}$ to $4.7 \times 10^{7} \cdot \mathrm{g}^{-1}$ of sediment. Reproduced from Pettibone \& Cooney (1988), by permission

Mechanisms of toxicity to microorganisms were reviewed by Cooney \& Wuertz (1989). Briefly, organotins are likely to accumulate in lipid-rich organelles, and they penetrate biological membranes more readily than inorganic tin. TBT acts as an ionophore, facilitating halide-hydroxyl exchanges, and interferes with energy transduction processes in bacteria, chloroplasts and mitochondria (Aldridge, 1986; Cooney \& Wuertz, 1989; Selwyn, 1976). TBT also inhibits energy-linked reactions in E. coli (Singh \& Singh, 1985) and Legionella pneumophila (Soracco \& Pope, 1983). Effects include dissipation of $\Delta \mathrm{pH}$, and inhibition of: ATPase, oxidation of substrates, glycolysis, solute transport and energy-linked transhydrogenase (reviewed by Cooney \& Wuertz, 1989). TBT inhibits microsomal cytochrome $P-450$ in fish (Fent \& Stegeman, 1991), and perhaps it can in algae and fungi as well. Effects on mitochondria and chloroplasts include gross swelling, action as ionophores, and inhibition of ATPase (reviewed by Cooney \& Wuertz, 


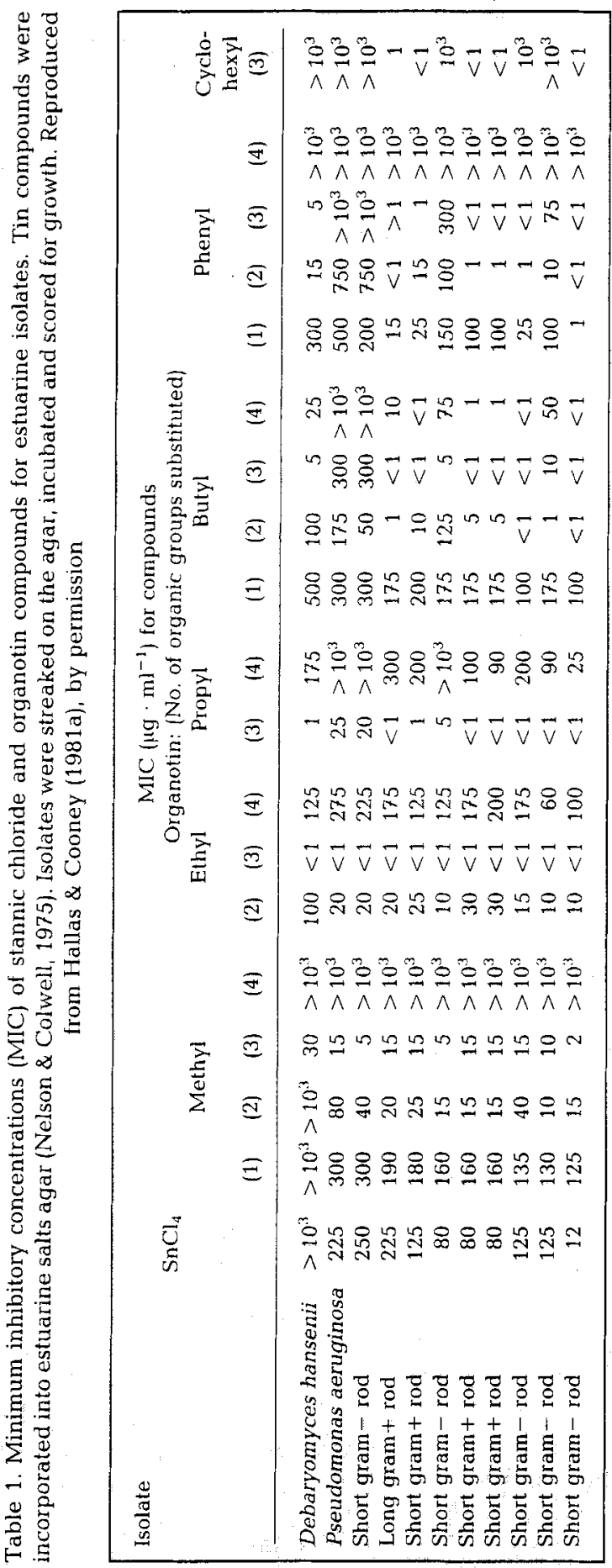




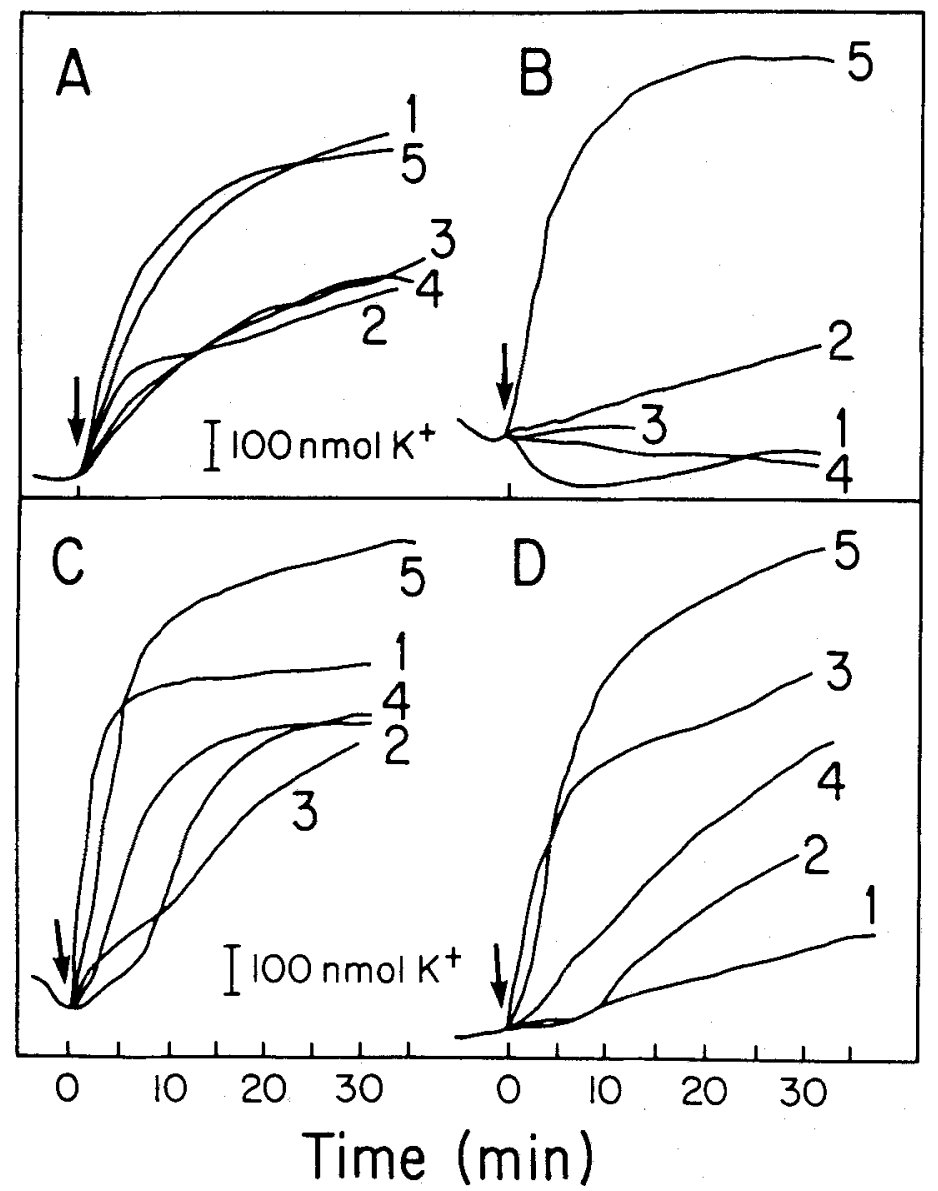

Fig. 2. Organotin-induced release of $\mathrm{K}^{+}$from five yeasts. A: monobutyltin trichloride; $\mathrm{B}$ : dibutyltin dichloride; C: tributyltin chloride; D: triphenyltin chloride. Final concentrations in the cell suspension were 50 mmolar. 1 . Aureobasidium pullulans; 2 . Debaryomyces hansenii NS-75-21; 3. Pichia pinus; 4 . Saccharomyces cerevisiae $\mathrm{X} 2180-1 \mathrm{~B}_{i} 5$. Zygosaccharomyces rouxii. Organometal solution was added where indicated by the arrow. Reproduced from Cooney et al. (1989), by permission

1989). Disubstituted organotins inhibit enzymes which have dithiol functions, and di- and trisubstituted organotins are active against a number of enzymes (cf. Cooney \& Wuertz, 1989; Davies \& Smith, 1980).

Considerable caution must be used in extrapolating to the field from results obtained in the laboratory. As with other metals, a large number of conditions can influence the apparent toxicity of a metal or organometal (Babich \& Stotzky, 1980, 1983; Cooney \& Pettibone, 1986). Different methods for estimating toxicity can yield values which differ by as much as 100-fold (Jonas et al., 1984). As shown in Table 2, methyltins appear to be less toxic to bacteria from estuarine sediment when judged by thymidine uptake, than when judged by viable counts. Changing the organic (Table 3; Wuertz et al., 1991) or 


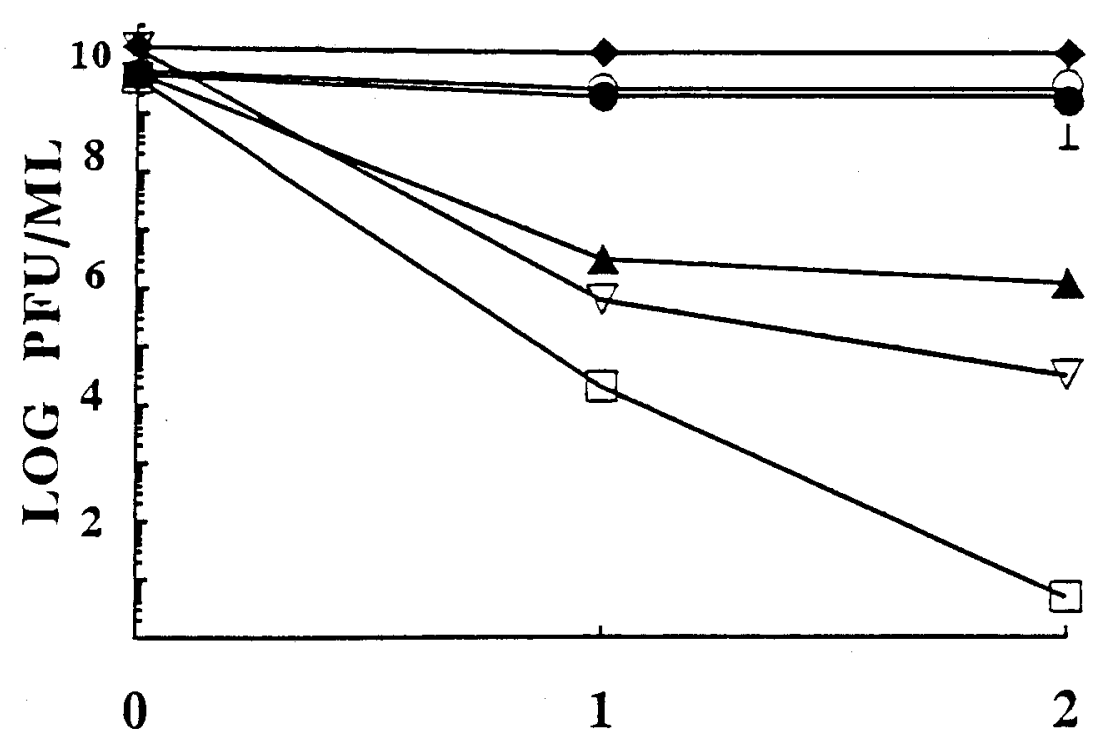

\section{TIME (days)}

Fig. 3. Effect of tin compounds on infectivity of phage T4. Phage were incubated with $84 \mu \mathrm{M}$ of the indicated tin compound at $\mathrm{pH} 6$ and at $18 \mathrm{C}$ for the times indicated. Error bars indicate the standard error of the mean (SEM). Where no bar is shown, the SEM was smaller than the symbol. $\bullet$ no tin added; $\mathrm{Sn}^{2+}$; O TBT; $\triangle \mathrm{DBT} ; \nabla \mathrm{MBT} ; \square \mathrm{Sn}^{4+}$. The no-tin control received methanol. Reproduced from Doolittle \& Cooney (1992), by permission

inorganic (Hallas et al., 1982b) composition of the assay medium can alter the apparent toxicity. Large molecules - such as humic acid or the protein, gelatin - can bind tin, making it inaccessible to the bacterium and decreasing apparent toxicity of the tin compound. It was suggested that small molecules such as serine or hydroxyflavone, which are known to bind tin and which increase the apparent toxicity, may carry the tin

Table 2. Comparative toxicities of three organotin compounds to natural populations from sediments in Boston Harbour as estimated by viable counts or by thymidine uptake. From Pettibone \& Cooney (1988), by permission

\begin{tabular}{|c|c|c|c|c|c|c|}
\hline \multirow{3}{*}{$\begin{array}{l}\text { Test } \\
\text { compound }\end{array}$} & \multicolumn{6}{|c|}{ Sn concentration $(\mathrm{mg} / 1)$} \\
\hline & \multicolumn{3}{|c|}{ Viable count } & \multicolumn{3}{|c|}{ Thymidine uptake } \\
\hline & $\mathrm{LC}_{20}{ }^{*}$ & $\mathrm{LC}_{50}$ & $\mathrm{LC}_{80}$ & $\mathrm{LC}_{20}$ & $\mathrm{LC}_{50}$ & $\mathrm{LC}_{80}$ \\
\hline $\mathrm{CH}_{3} \mathrm{SnCl}_{3}$ & 4.3 & 11 & 17 & 26 & 43 & $>50$ \\
\hline$\left(\mathrm{CH}_{3}\right)_{2} \mathrm{SnCl}_{2}$ & 2.9 & 7.2 & 11.6 & 8.0 & 23 & $>50$ \\
\hline$\left(\mathrm{CH}_{3}\right)_{3} \mathrm{SnCl}$ & 1.5 & 3.7 & 5.9 & 6.2 & 17 & 45 \\
\hline
\end{tabular}


Table 3. Effect of organic ligands on the toxicity of stannic chloride to sediment microorganisms. From Hallas at al. (1982b), by permission

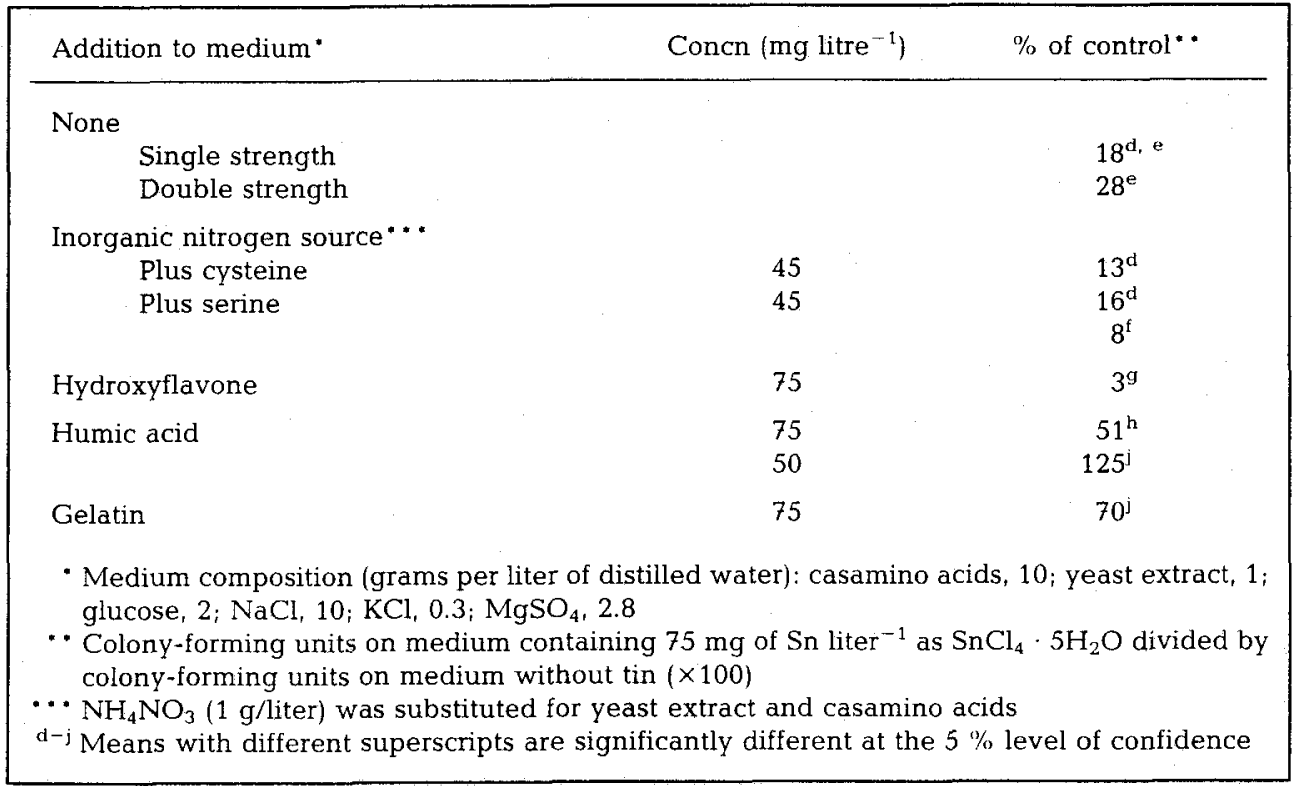

compound with them if they are transported into the cell (Hallas et al., 1982b). Moreover, different results are obtained in solid and liquid media (Hallas et al., 1982b; Wuertz et al., 1991). We have adopted a working definition of a TBT-sensitive bacterium as one which does not grow on trypticase soy agar containing $8.4 \mu \mathrm{M}$ TBT, a concentration which inhibits the growth of about $90 \%$ of the culturable bacteria from fresh or saltwater sediments (Wuertz et al., 1991). Methods which depend on diffusion of a toxicant through agar cannot be used to compare the toxicity of one tin compound with another, because organotins differ strongly in their solubility, and may of them are essentially waterinsoluble. If one hopes to extrapolate from the laboratory to the environment, considerable caution should be used and the conditions used in the laboratory should approximate field conditions as closely as is feasible.

\section{ACTION OF MICROORGANISMS ON ORGANOTINS}

Methylation. Among the organisms which survive stress by tin compounds, are some which can methylate inorganic or organic tin compounds. Methyltins are widely distributed. They have been found in rain, in a variety of natural waters and in sediments (Byrd \& Andreae, 1982; Maguire, 1987; Schebek \& Andreae, 1991; Seligman et al., 1991; Thompson et al., 1985; and others). They may be formed by biotic or abiotic methylation, or be derived from anthropogenic sources, since they are widely used in industry. The relative contributions of these sources is poorly understood

Tin compounds can be methylated by natural populations of microorganisms brought into the laboratory and incubated in natural water and sediment or in nutrient medium 
under aerobic conditions. $\mathrm{SnCl}_{2}$ and $\mathrm{SnCl}_{4}$ (Chau et al., 1981; Cooney et al., 1981; Hallas et al., 1982a) or methyltins (Chau et al., 1981; Guard et al., 1981) can be methylated. Algae may be important contributors to methylation (Lee et al., 1989). Pure cultures can also effect methylation. A Pseudomonas sp. methylated $\mathrm{Sn}^{2+}$ and $\mathrm{Sn}^{4+}$, yielding di- and trimethyltin compounds, including the stannanes, and probably tetramethyltin (Blair et al., 1981; Jackson et al., 1982). It is significant that methyltin(s) produced by the Pseudomonas sp. can methylate $\mathrm{Hg}^{2+}$ abiotically (Huey et al., 1974). Two Bacillus spp. isolated from estuarine sediments methylated monomethyltin. Neither organism alone accomplished the methylation (Makkar \& Cooney, 1990). This suggests that microbial consortiums may be involved in methylation in situ.

Methylation can also occur anaerobically. Slurries prepared from sulfide-rich sediments incubated anaerobically methylated $\mathrm{Sn}^{4+}$, and did so more rapidly than slurries incubated aerobically. Samples from sediment cores also produced mono-, di- and trimethyltins. Desulfovibrio spp. isolated from the sediments methylated at the same rate as the mixed flora in slurries (Gilmour et al., 1985).

Butylmethyltins were found in sediments of several Canadian harbours (Maguire, 1984). Since TBT from antifouling paints is the principal source of tin in those harbours, these observations suggest strongly that butyltins can be partially degraded and then methylated in situ.

Organotin compounds can give rise to one another by disproportionation reactions such as:

$$
2 \mathrm{R}_{3} \operatorname{SnX}<----->>\mathrm{R}_{2} \operatorname{Sn} \mathrm{X}_{2}+\mathrm{R}_{4} \mathrm{Sn} \text {. }
$$

The extent of disproportionation reactions in the aquatic environment and their contribution to the geochemical cycling of tin is poorly understood (Blunden et al., 1990; Thompson et al., 1985). They make it more difficult to establish the role of microorganisms in the geochemical cycling of tin.

In summary, a number of the transformations in the "tin cycle" proposed by Ridley et al. (1977) can occur under laboratory conditions. Methylations are environmentally important because methylation increases the volatility, the lipid solubility, the adsorptivity and the toxicity of tin, and probably its mobility in the environment.

Degradation of butyltins. In the marine water column, TBT can be degraded rapidly to DBT and MBT with a half-life of several days (Seligman et al., 1994). Photolytic degradation also occurs but it proceeds slowly, with a half-life of $>89$ days (Maguire and Tkacz, 1985). Light stimulates degradation (Seligman et al., 1989) when microalgae are present (Lee et al., 1989) and when nutrients are added (Meyers-Schulte \& Dooley, 1990). The green alga Ankistrodesmus falcatus degraded TBT to inorganic tin (Maguire et al., 1984). Exposure of water samples from Chesapeake Bay to light, was necessary to obtain TBT degradation (Olson \& Brinckman, 1986). These results suggest that photosynthetic organisms may be involved in the degradation.

In sediments, where most of the TBT resides, degradation is slower, with a half-life of several months (Maguiere \& Tkacz, 1985), years (deMora et al., 1989) or absent (Adelman et al., 1990). Although a strain of Pseudomonas aeruginosa and several wood-decaying fungi can degrade TBT, efforts to isolate organisms which can degrade it under aerobic or anaerobic conditions have not been successful in our laboratory or elsewhere (Blair et al., 1982; Olson \& Brinckman, 1986). This suggests that microbial consortiums and/or cometabolic events may be involved. Mammals, fish and crustaceans can hydroxylate the 
butyl moiety, as well as debutylate TBT (Fish et al., 1975; Lee, 1991), but hydroxylated metabolites have not been demonstrated in microorganisms. Stang et al. (1992) obtained limited biotic degradation of TBT to MBT and inorganic tin in sediments, but sterile, surficial, fine-grained sediments degraded more extensively, to MBT and inorganic tin. The relative contributions of biotic and abiotic degradation remain to be determined in sub-surficial and anaerobic sediments.

Other organotins undoubtedly make their way to the aquatic environment. For example, triphenyltin has been reported in fish tissue (Tas \& Opperhuizen, 1991). What little is known of interactions between other organotins and microorganisms is available in reviews (Cooney, 1988; Cooney \& Wuertz, 1989).

TB T-resistant microorganis ms. We have developed a working definition of a tin-resistant microorganism, as one which grows in the presence of an amount of tin which kills $90 \%$, or more, of the culturable population. For $\mathrm{SnCl}_{4}$, this was $0.63 \mu \mathrm{M}$ in an estuarine salts agar (Hallas \& Cooney, 1981a) and for TBT, this was $8.4 \mu \mathrm{M}$ in trypticase soy agar (Wuertz et al., 1991). These are pragmatic definitions. Since chemical, biological and physical conditions can influence the apparent toxicity of tin compounds, one should adjust one's working definition to the individual situation.

TBT-resistant bacteria from fresh and estuarine sediments showed a high incidence of resistances to antibiotics and to inorganic forms of heavy metals (Wuertz et al., 1991). Five out of ten estuarine and 12 of 19 freshwater isolates examined contained plasmids. Since some TBT-resistant organisms lack plasmids, TBT-resistance need not be plasmidmediated. However, when a chromate-resistant and TBT-resistant Pseudomonas aeruginosa (which harbours plasmid pCRO1), was cured of the plasmid, it lost TBTresistance. Pseudomonas fluorescens BP4 has four plasmids. In conjugation experiments, it will donate all of them to another strain of $P$. fluorescens and the TBT-resistance of the recipient is increased 10 -fold (Miller et al., unpubl.). Thus, TBT-resistance can be plasmid-mediated.

\section{REGULATION OF TRIBUTYLTINS}

Because of its effects on non-target organisms at levels as low as $8.4 \mathrm{pM}$ (1 part Sn per trillion), TBT has been called "perhaps the most acutely toxic chemical to aquatic organisms ever deliberately introduced to water", (Maguire, 1987). Thus, TBT has attracted the attention of environmental protection agencies in a number of countries. The first regulation of TBT was in France in 1982, followed by the United Kingdom, Ireland, Germany and Switzerland. The British regulation restricted the amount of tin in antifouling paints, but did not restrict their use. The regulation did not have the desired effect, and in 1987 the use of TBT-paints was banned on small boats and mariculture equipment (Vosser, 1987). In 1988 TBT was regulated in the US. The effective regulations are similar in all countries: paints with TBT may not be used on boats shorter than 25 metres; aluminium-hulled boats are exempt, because copper-based paints will contribute to hull electrolysis. Huggett et al. (1992) provided a useful, brief summary of a number of monitoring studies in the environment and in animals, and of the regulatory history in the US. The restriction on use of paints with TBT has resulted in decreased levels in the environment (Alzieu, 1991; Cleary, 1991; Huggett et al., 1992) and a decrease in effects on shellfish populations (Alzieu, 1986; Bailey \& Davies, 1991; Waite et al., 1991). Levels in sediments do not appear to be decreasing as rapidly (Waite et al., 1991), and levels in 
water and sediments at many sites exceed acceptable levels (Alzieu et al., 1991). Moreover, paints containing triphenyltin (TPT), which is not covered by the regulations, are now being introduced. TPT is appearing in the environment around marinas and harbours and in fish (Alzieu et al., 1991; Fent \& Hunn, 1991; Schebek \& Andreae, 1991; Tas \& Opperhuizen, 1991). Little is known about the fate and effects of TPT, particularly its interactions with microorganisms.

The TBT story, and stories of other organotins, are not over. The role of microorganisms in their bioaccumulation, transformation, mobilization and degradation is poorly understood - as is the potential use of microorganisms for bioremediating waste streams, and polluted harbours and marinas. We should explore the activities of microbial communities and consortiums in effecting these changes. Similarly, microorganisms can serve as models to expand our understanding of how organotins interact with organisms at the cellular, biochemical and genetic levels.

\section{LITERATURE CITED}

Adelman, D., Hinga, K. R. \& Pilson, M. E. Q., 1990. Biogeochemistry of butyltins in an enclosed marine ecosystem. - Environ. Sci. Technol. 24, 1027-1032.

Aldridge, W. N., 1986. The toxicology and biological properties of organotin compounds. In: Tin as a vital nutrient. Ed. by N. F. Cardarelli. CRC Press, Boca Raton, 245-261.

Alzieu, C., 1986. TBT detrimental effects on oyster culture in France - evolution since antifouling paint regulation. - Oceans 86 (4), 1130-1134.

Alzieu, C., 1991. Environmental problems caused by TBT in France: assessment, regulations, prospects. - Mar. environ. Res. 32, 7-17.

Alzieu, C., Michel, P., Sanjuan, J. \& Averty, B., 1990. Tributyltin levels in French Mediterranean coastal waters. - Appl. organomet. Chem. 4, 55-61.

Alzieu, C., Michel, P., Tolosa, I., Bacci, E., Mee, L. D. \& Readman, J. W., 1991. Organotin compounds in the Mediterranean: a continuing cause for concern. - Mar. environ. Res. 32, 261-270.

Ashby, J., Clark, S. \& Craig, P. J., 1988. The analysis of organotin compounds from environmental matrices. In: The biological alkylation of heavy elements. Ed. by P. J. Craig \& F. Glocking. Royal Soc. Chem., London, 263-290.

Babich, H. \& Stotzky, G., 1980. Environmental factors that influence the toxicity of heavy metals and gaseous pollutants to microorganisms. - Crit. Rev. Microbiol. 8, 99-145.

Babich, H. \& Stotzky, G., 1983. Heavy metal toxicity to microbe-mediated ecological processes: a review and potential application to regulatory policies. - Environ. Res. 36, 111-137.

Bailey, S. K. \& Davies, I. M., 1991. Continuing impact of TBT, previously used in mariculture, on dogwhelk (Nucella lapillus L.) populations in a Scottish sea loch. - Mar. environ. Res. 32, $187-199$.

Beaumont, A. R. \& Budd, M. D., 1984. High mortality of the larvae of the common mussel at low concentrations of tributyltin. - Mar. Pollut. Bull. 15, 402-405.

Belay, N., Rajagopal, B. S. \& Daniels, L., 1990. Effects of alkyltin compounds on hydrogen-oxidizing anaerobic bacteria. - Curr. Microbiol. 20, 329-334.

Blair, W. R., Jackson, J. A., Olson, G. J., Brinckman, F. E. \& Iverson, W. P., 1981. Biotransformation of tin. In: Proceedings of the International Conference on Heavy Metals in the Environment. CEP Consultants, Edinburgh, 235-242.

Blair, W. R., Olson, G. J., Brinckman, F. E. \& Iverson. W. P., 1982. Accumulation and fate of tri- $n-$ butyltin cation in estuarine bacteria. - Microb. Ecol, 8, 241-251.

Blair, W. R., Olson, G. J., Brinckman, F. E., Paule, R. C. \& Becker, D. A., 1986. An international butyltin measurement intercomparison: sample preparation and results of analyses. National Bureau of Standards, Gaithersburg, $31 \mathrm{pp}$.

Blunden, S. J., Harston, P., Hill, R. \& Wardell, J., 1990. Disproportionation of triorganotin species, R3SnX: - Appl. organomet. Chem. 4, 383-385. 
Blunden, S. J., Hobbs, L. A. \& Smith, P. J., 1984. The environmental chemistry of organotin compounds. In: Environmental chemistry. Ed. by H. J. Bowen. Royal. Soc. Chem., London, 49-77.

Boopathy, R. \& Daniels, L., 1991. Pattern of organotin inhibition of methanogenic bacteria. - Appl. environ. Microbiol. 57, 1189-1193.

Byrd, J. T. \& Andreae, M. O., 1982. Tin and methyltin species in seawater: concentrations and fluxes. - Science, N.Y. 218, 565-569.

Champ, M. A., 1986. Organotin symposium: introduction and overview. - Oceans 86 (4), 1093-1100.

Champ, M. A. \& Pugh, W. L., 1987. Tributyltin antifouling paints: introduction and overview. Oceans $87(4), 1296-1308$.

Chau, Y. K., Wong, P. T. S., Kramar, O. \& Bengert, G. A., 1981. Methylation of tin in the aquatic environment. In: Proceedings of the 3rd International Conference on Heavy Metals in the Environment. CEP Consultants, Edinburgh, 641-644.

Cleary, J. J., 1991. Organotin in the marine surface microlayer and subsurface waters of south-west England: relation to toxicity thresholds and the UK environmental quality standard. - Mar. environ. Res. 32, 213-222.

Cleary, J. J. \& Stebbing, A. R. D., 1985. Organotin and total tin in coastal waters of southwest England. - Mar. Pollut. Bull. 16, 350-355.

Cooney, J. J., 1988. Microbial transformations of tin and tin compounds. - J. ind. Microbiol. 3 , 195-204.

Cooney, J. J. \& Pettibone, G. W., 1986. Metals and microbes in toxicity testing. - Toxicity Assessm. 1, $487-499$

Cooney, J. J. \& Wuertz, S. W., 1989. Toxic effects of tin compounds on microorganisms. - J. ind. Microbiol. 4, 375-402.

Cooney, J. J., Hallas, L. E. \& Means, J. C., 1981. Tin and microbes in the Chesapeake Bay, USA. In: Proceedings of the 3rd International Conference on Heavy metals in the Environment. CEP Consultants, Edinburgh, 413-482.

Cooney, J. J., deRome, L., Laurence, O. \& Gadd, G. M., 1989. Effects of organotin and organolead compounds on yeasts. - J. ind. Microbiol. 4, 279-288.

Cullen, W. R., Eigendorf, G. K., Nwata, B. U. \& Takatsu, A., 1990. The quantitation of butyltin and cyclohexyltin compounds in the marine environment of British Columbia. - Appl. organomet. Chem. 4, 581-590.

Davies, A. \& Smith, P. J., 1980. Recent advances in organotin chemistry. - Adv. inorg. Chem. Radiochem, 23, 1-77.

Davies, A. G. \& Smith, P. E., 1982. Tin. In: Comprehensive organometallic chemistry: the synthesis, reactions and structures of organometallic compounds. Ed. by G. Wilkinson, F. G. A. Stone \& W. W. Abel. Pergamon Press, New York 2, 519-627.

Davies, I. M., McKie, J. C. \& Paul, J. D., 1986. Accumulation of tin and tributyltin from antifouling paint by cultivated scallops (Pectin maximus) and Pacific oysters (Crassostrea gigas). - Aquaculture $55,103-114$.

deMora, S. J., King, N. G. \& Miller, M. C., 1989. Tributyltin and total tin in sediments: profiles and the apparent rate of TBT degradation. - Environm. Technol. Lett. 10, 901-908.

Donard, O. F. X. \& Weber, J. H., 1985. Behaviour of methyltin compounds under simulated conditions. - Environ. Sci. Technol. 19, 1104-1110.

Doolittle, M. M. \& Cooney, J. J., 1992. Inactivation of bacteriophage T4 by organic and inorganic tin compounds. - J. ind. Microbiol. 10, 221-228.

Eng, G., Tierney, E. J., Bellama, J. M. \& Brinckman, F. E., 1988. Correlation of molecular total surface area with organotin toxicity for biological and physicochemical applications. - Appl. organomet. Chem. 2, 171-175.

Fent, K., 1991. Bioconcentration and elimination of tributyltin chloride by embryos and larvae of minnows Phoxinus phoximus. - Aquat. Toxicol. 20, 147-158.

Fent, K. \& Hunn, J., 1991. Phenyltins in water, sediment and biota of freshwater marinas, - Environ. Sci. Technol. 25, 956-963.

Fent, K. \& Mueller, M. D., 1991. Occurrence of organotins in municipal wastewater and sewage sludge and behavior in a treatment plant. - Environ. Sci. Technol. 25, 489 493.

Fent, K. \& Stegeman, J. J., 1991. Effects of tributyltin chloride in vitro on the hepatic microsomal monooxygenase system in the fish Stenotomus chrysops. - Aquat. Toxicol. 20, 159-168. 
Fish, R. H., Kimmel, E. C. \& Casida, J. E., 1975. Bioorganotin chemistry: biological oxidation of tributyltin derivatives. - J. organomet. Chem. 93, C1-C4.

Froelich, P. N., Kaul, L. W., Byrd, J. T., Andreae, M. O. \& Roe, K. K., 1985. Arsenic, barium, germanium, tin, dimethylsulfide and nutrient biogeochemistry in Charlotte Harbor, Florida, a phosphorus-enriched estuary. - Estuar. coast. Shelf Sci. 20, 239-264.

Gibbs, P. E. \& Bryan, G. W., 1986. Reproductive failure in populations of the dogwhelk, Nucella lapillus, caused by imposex induced by tributyltin from antifouling paints. - J. mar. biol. Ass. U.K. $66,767-777$.

Gibbs, P. E., Bryan, G. W. \& Pascoe, P. L., 1991. TBT-induced imposex in the dogwhelk, Nucellus lapillus: geographical uniformity of the response and effects. - Mar. environ. Res. 32, $79-87$.

Gilmour, C. C., Tuttle, J. H. \& Means, J. C., 1985. Tin methylation in sulfide bearing sediments. In: Marine and estuarine geochemistry. Ed. by A. C. Sigleo \& A. Hattori. Lewis, Chelsea, 239-258.

Guard, H. E., Cobet, A. B. \& Coleman, W. M., 1981. Methylation of trimethyltin compounds by estuarine sediments. - Science, N.Y. 213,770-771.

Hall, L. W., Jr. \& Pinkney, A. E., 1985. Acute and sublethal effects of organotin compounds on aquatic biota: an interpretative literature evaluation. - CRS crit. Rev. Toxicol. 14, 159-209.

Hallas, L. E. \& Cooney, J. J., 1981a. Effects of stannic chloride and organotin compounds on estuarine microorganisms. - Devs. ind. Microbiol. 22, 529-535.

Hallas, L. E. \& Cooney, J. J., 1981b. Tin and tin-resistant microorganisms in Chesapeake Bay. - Appl. environ. Microbiol. 41, 466-471.

Hallas, L. E., Means, J. C. \& Cooney, J. J., 1982a. Methylation of tin by estuarine microorganisms. Science, N.Y. 215, 1505-1507.

Hallas, L. E., Thayer, J. S. \& Cooney, J. J., 1982b. Factors affecting the toxic effect of tin on estuarine microorganisms. - Appl. environ. Microbiol. 44, 193-197.

Han, J. S. \& Weber, J. H., 1988. Speciation of methyl- and butyltin compounds and inorganic tin in oysters by hydride generation atomic absorption spectrometry. - Analyt. Chem. 60, 316-319.

Harris, J. R. W. \& Cleary, J. J., 1987. Particle-water partitioning and organotin dispersal in an estuary, - Oceans $87(4), 1370-1374$.

Huey, C., Brinckman, F. E., Grim, S. \& Iverson, W. P., 1974. The role of tin in the bacterial methylation of mercury. Proc. Int. Conf. Transport Persistent Chem. Aquat. Syst. Ed. by A. S. W. de Freitas, D. J. Kushner, Q. M. LaHam \& S. A. Quadri. National Research Council Canada, Ottawa (2), 73-78.

Huggett, R. J., Unger, M. A., Seligman, P. F. \& Valkirs, A. O., 1992. The marine biocide tributyltin. Environ. Sci. Technol. 26, 232-237.

Jackson, J. A., Blair, W. R., Brinckman, F. E. \& Iverson, W. P., 1982. Gas-chromatographic speciation of methylstannanes in the Chesapeake Bay using purge and trap sampling with a tin-selective detector. - Environ. Sci. Technol. 16, 110-119.

Jonas, R. B., Gilmour, C. C., Stoner, D. L., Weir, M. M. \& Tuttle, J. H., 1984. Comparison of methods to measure acute metal and organometal toxicity to natural aquatic microbial communities. Appl. environ. Microbiol. 47, 1005-1011.

Langston, W. J. \& Burt, G. R., 1991. Bioavailability and effects of sediment-bound TBT in depositfeeding clams, Scrobularia plana. - Mar. environ. Res. 32, 61-67.

Lee, R. F., 1991. Metabolism of tributyltin by marine animals and possible linkages to effect. - Mar. environ. Res. 32, 29-35.

Lee, R. F., Valkirs, A. O. \& Seligman, P. F., 1989. Importance of microalgae in the biodegradation of TBT in estuarine waters. - Environ. Sci. Technol. 23, 1515-1518.

Levine, S. N., Rudnick, D. T., Kelly, J. R., Morton, R. D., Buttel, L. A. \& Carr, K. A., 1990. Pollutant dynamics as influenced by seagrass beds: experiments with tributyltin in Thalassia microcosms. - Mar, environ. Res. 30, 297-322.

Luijten, J. G. A., 1972. Applications and biological effects of organotin compounds. In: Organotin compounds. Ed. by A. K. Sawyer. Dekker, New York 3, 931-974.

Mackie, G. L., Gibbons, W. N., Muncaster, B. W. \& Gray, I. M., 1989. The zebra mussel, Dreissena polymorpha: a synthesis of European experiences and a preview for North America. Environment Ontario, Queen's Printer for Ontario, Ontario, $75 \mathrm{pp}$.

Maguire, R. J., 1984. Butyltin compounds and inorganic tin in sediments in Ontario. - Environ. Sci. Technol. 18, 291-294. 
Maguire, R. J., 1987. Environmental aspects of tributyltin. - Appl organomet. Chem. 1, 475-498.

Maguire, R. J. \& Tkacz, R. K., 1985. Degradation of tri- $n$-butyltin species in water and sediment from Toronto Harbor. - J. Agric. Food Chem. 33, 947-953.

Maguire, R. J. \& Tkacz, R. K., 1987. Concentration of tributyltin in the surface microlayer of natural waters. - Wat. Pollut. Res. Can. 22, 227-233.

Maguire, R. J., Wong, P. T. S. \& Rhamey, J. S., 1984. Accumulation and metabolism of tri-n-butyltin cation by a green alga, Ankistrodesmus falcatus. - Can. J. Fish. aquat. Sci. 41, 537-540.

Makkar, N. S. \& Cooney, J. J., 1990. Methylation of monomethyltin by a bacterial coculture. Geomicrobiol J. 8, 101-107.

Meyers-Schulte, K. J. \& Dooley, C. A., $1990,{ }^{124} \mathrm{Sn}$ as a tracer of tributyltin degradation in seawater. Mar. Chem. 39, 339-354.

Oehlmann, J., Stroben, E. \& Fiorini, P., 1991. The morphological expression of imposex in Nucella lapillus (Linnaeus) (Gastropoda: Muricidae). - J. moll. Stud. 57, 375-390.

Olson, G. J. \& Brinckman, F. E., 1986. Biodegradation of tributyltin by Chesapeake Bay microorganisms. - Oceans $86(4), 1196-1201$.

Pettibone, G. W. \& Cooney, J. J., 1986. Effect of organotins on fecal pollution indicator organisms. Appl. environ. Microbiol. 52, 562-566.

Pettibone, G. W. \& Cooney, J. J., 1988. Toxicity of methyltins to microbial populations in estuarine sediments. - J. ind. Microbiol. 2, 373-378.

Quevauviller, Ph. \& Donard, O. F. X., 1990. Variability of butyltin determination in water and sediment samples from European coastal environments. - Appl. organomet. Chem, 4, 353-367.

Randall, L. \& Weber, J. H., 1986. Adsorptive behavior of butyltin compounds under simulated estuarine conditions. - Sci. total Environ. 57, 191-203.

Ridley, W. P., Dizikes, L. J. \& Wood, J. M., 1977. Biomethylation of toxic elements in the environment. - Science, N.Y. 197, 329-332.

Schebek, L. \& Andreae, M. O., 1991. Methyl-and butyltin compounds in water and sediments of the Rhine River. - Environ. Sci. Technol. 25, 871-878.

Seidel, S. V., Hodge, V. F. \& Goldberg, E. D., 1980. Tin as an environmental pollutant. - Thalassia Jugosl. 16, 209-223.

Seligman, P. F., Valkirs, A. O. \& Lee, R. F., 1986. Degradation of tributyltin in San Diego Bay, California, Waters. - Environ. Sci. Technol. 20, 1229-1235.

Seligman, P. F., Grovhoug, J. G., Valkirs, A. O., Stang, P. M., Francham, R., Stallard, M. O., Davidson, B. \& Lee, R. F., 1989. Distribution and fate of tributyltins in the U.S. marine environment. - Appl. organomet. Chem. 3, 31-47.

Seligman, P. F., Maguire, R. J., Lee, R. F., Hinga, K. R., Valkirs, A. O. \& Stang, P. M., 1994. Persistence and fate of tributyltin in aquatic ecostyms. In: Organotins: environmental fates and effects. Ed. by M. Champ \& F. F. Seligman. Elsevier, London (in press).

Selwyn, M. J., 1976. Triorganotin compounds as ionophores and inhibitors of ion-translocating ATPases. - Adv. Chem. Ser. 157, 205-227.

Short, J. W. \& Thrower, F. P., 1986. Accumulation of butyltins in muscle tissue of chinook salmon reared in sea pens treated with tri-n-butyltin. - Oceans 86 (4), 1177-1181.

Sijpesteijn, K. A., Luijten, J. G. A. \& Van der Kirk, G. J. M., 1969. Organometallic fungicides. In: Fungicides - an advanced treatise. Ed. by D. C. Torgeson. Acad. Press, New York 2, 331-336.

Singh, A. P. \& Singh, K., 1985. Differential sensitivity to TBT of cytochrome-containing and cytochrome-deficient cells of Escherichia coli SASX76. - Experientia 41, 764-767.

Soracco, R. J. \& Pope, D. H., 1983. Bacteriostatic and bactericidal modes of action of bis(tributyltin)oxide on Legionella pneumophila. - Appl. environ. Microbiol. 45, 48-57.

Spence, S. K., Bryan, G. W., Gibbs, P. E., Masters, D., Morris, L. \& Hawkins, S. J., 1990. Effects of TBT contamination on Nucella populations. - Funct. Ecol. 4, 425-432.

Spiegel, S. J., Farmer, J. K. \& Garver, S. R., 1985. Heavy metal concentrations in municipal wastewater treatment plant sludge. - Bull. environ. Contam. Toxicol. 35, 38-43.

Spooner, N., Gibbs, P. E., Bryan, G. W. \& Goad, L. J., 1991. The effect of tributyltin upon steroid titres in the female dogwhelk, Nucella lapillus, and the development of imposex. - Mar. environ. Res. $32,37-49$.

Stallard, M. O., Cola, S. Y. \& Dooley, C. A., 1989. Optimization of butyltin measurements for seawater, tissue and marine sediment samples. - Appl. organomet. Chem. 3, 105-114. 
Stang, P. M., Lee, R. F. \& Seligman, P. F, 1992. Evidence for rapid, nonbiological degradation of tributyltin compounds in autoclaved and heat-treated fine-grained sediments. - Environ. Sci. Technol. 26, 1382-1387.

Tas, J. W. \& Opperhuizen, A., 1991. Analysis of triphenyltin in fish. - Mar. environ. Res. 32, 271-278.

Thayer, J. S., 1984. Organometallic compounds and living organisms. Acad. Press, New York, $273 \mathrm{pp}$.

Thompson, J. A. J., Sheffer, M. G., Pierce, R. C., Chay, Y. K., Cooney, J. J., Cullen, W. R. \& Maguire, R. J., 1985. Organotin compounds in the aquatic environment. National Res. Council Canada, Ottawa, $284 \mathrm{pp}$.

Unger, M. A., MacIntyre, W. G. \& Huggett, R. J., 1987. Equilibrium sorption of tributyltin chloride by Chesapeake Bay sediments. - Oceans 87 (4), 1381-1385.

Valkirs, A. O., Seligman, P. F. \& Lee, R. F., 1986. Butyltin partitioning in marine waters and sediments. - Oceans $86(4), 1165-1170$.

Valkirs, A. O., Seligman, P. F., Olson, G. J., Brinckman, F. E., Matthias, C. L. \& Bellama, J. M., 1987. Di- and tributyltin species in marine and estuarine waters. - Analyst, Lond. 112, 17-20.

Valkirs, A. O., Seligman, P. F., Stang, P. M., Homer, V., Lieberman, S. M., Vafa, G. \& Dooley, C. A., 1986. Measurement of butyltin compounds in San Diego Bay. - Mar. Pollut. Bull. 7, 319-324.

Vosser, J. L., 1987. Antifouling paints news release. Dept. of Environ., London.

Waite, M. E., Waldock, M. J., Thain, J. E., Smith, D. J. \& Milton, S. M., 1991. Reductions in TBT concentrations in UK estuaries following legislation in 1986 and 1987. - Mar. environ. Res. 32, 89-111.

Waldock, M. J. \& Thain, J. E., 1983. Shell thickening in Crassostrea gigas: organotin antifouling or sediment induced? - Mar. Pollut. Bull. 14, 411-415.

Wuertz, S., Miller, C. E., Pfister, R. M. \& Cooney, J. J., 1991. Tributyltin-resistant bacteria from estuarine and freshwater sediments. - Appl. environ. Microbiol. 57, 2783-2789. 